\title{
Serbest Dolaşan Tavuk, Hindi ve Ördek Civcivlerinde Görülen Felç ve Ölümlerin Etiyolojik Araştırması
}

\author{
Bilge Kaan Tekelioğlu ${ }^{*}$, Osman Barış Derici² ${ }^{2}$ Utku Yusuf Çizmecigil ${ }^{3 a}$, Mehmet Çelik ${ }^{4}$, Aydın Gürel ${ }^{5 a}$, Özge \\ Erdoğan Bamaç $^{5 b}$, Nuri Turan ${ }^{3 b}$, Özge Aydın ${ }^{3 c}$, Hüseyin Yılmaz ${ }^{3 \mathrm{~d}}$
}

\begin{abstract}
1* Çukurova Üniversitesi Ceyhan Veteriner Fakültesi, Viroloji Anabilim Dalı, Adana, Türkiye (ORCID: 0000-0001-6727-3175), ktekelioglu@cu.edu.tr ${ }^{2}$ Çukurova Arge, Çukurova Üniversitesi Teknokent Yerleşkesi B211A, Balcalı, Adana, Türkiye (ORCID: 0000-0001-7328-0224), info@cukurovaarge.com.tr

3 İstanbul Üniversitesi Cerrahpaşa Veteriner Fakültesi, Viroloji Anabilim Dalı, İstanbul, Türkiye a (ORCID: 0000-0001-7882-688X), utku.cizmecigil@iuc.edu.tr, b(ORCID: 0000-0003-1328-1473), nturan@iuc.edu.tr, ${ }^{\mathrm{c}}$ (ORCID: 0000-0002-5834-6106), ozge.aydin@ iuc.edu.tr, ${ }^{\mathrm{d}}$ (ORCID: 0000-0002-7897-2358), hyilmaz@iuc.edu.tr ${ }^{4}$ Çukurova Üniversitesi Ceyhan Veteriner Fakültesi, Gıda Hijyeni ve Teknolojisi, Adana, Türkiye (ORCID: 0000-0003-4330-2490), mcelik.cu@ gmai.com ${ }^{5}$ İstanbul Cerrahpaşa Üniversitesi Veteriner Fakültesi, Patoloji Anabilim Dalı, İstanbul, Türkiye, ${ }^{a}$ (ORCID: 0000-0002-0266-8771), agurel@ iuc.edu.tr , ${ }^{\mathrm{b}}$ (ORCID: 0000-0002-0352-4841), oerdogan@iuc.edu.tr
\end{abstract}

(International Conference on Design, Research and Development (RDCONF) 2021 - 15-18December 2021)

(DOI: 10.31590 /ejosat.1045575)

ATIF/REFERENCE: Tekelioğlu, B.K., Derici, O.B., Çizmecigil, U.Y., Çelik, M., Gürel, A., Bamaç, Ö.E., Turan, N., Aydın, Ö. \& Yılmaz, H. (2021). Serbest Dolaşan Tavuk, Hindi ve Ördek Civcivlerinde Görülen Felç ve Ölümlerin Etiyolojik Araştırması. Avrupa Bilim ve Teknoloji Dergisi, (32), 588-594.

$\ddot{O} \mathbf{z}$

$\mathrm{Bu}$ çalışmada, bir serbest dolaşan kanatlı hayvan aile işletmesinde bulunan tavuk, ördek ve hindi civcivlerinde arasında felç, sinir sistemi bozuklukları ve ölümlerin etiyolojisi araştırılmıştır. Hastalık hikayesinde hayvanlarda görülen sinirsel bulguların civcivlerin işletmeye gelişlerinden sonraki 11 ila 12. günleride başladığı, 2 ila 3. günlerde ölümlerin görüldüğü bildirilmiştir. Ölüm nedenlerinin saptanabilmesi ve etiyolojik inceleme için felçli ve ölüme yakın halde olan 6 tavuk, 12 ördek ve 21 hindi yavrusu ile yem örnekleri incelenmek üzere kurumumuza gönderilmiştir. Her hayvan grubundan felçli ve ölen hayvanlardan 1'er adet olmak üzere toplam 6 hayvana nekropsi yapılmış ve kullanılan yemlerden örnekler alınmıştır. Klinik semptomlar ve nekropsi bulgularına göre, zehirlenme, beslenme bozukluğu ve New Castle (ND) hastalığından şüphe edilmiştir. Örnekleme yapılan böbrek, karaciğer, bağırsak, beyin, akciğer ve kalp dokuları histopatolojik ve RT-PCR ile virolojik olarak incelenmiş̧ir. Yem analizleri atomik absorpsiyon spektrofotometresi kullanılarak incelenmiştir. Yem örneklerinde, Bakır (Cu), Çinko ( $\mathrm{Zn}$ ), Demir (Fe), Kurşun (Pb), Kadmiyum (Cd), Mangan (Mn) ve Selenyum (Se) miktarları araştırılmıştır. Sonuç; RT-PCR ile New Castle hastalığı virüsü (NDV) Avian Paramyxovirus Tip-1'e ait viral RNA saptanamamışır. Histopatolojik incelemede enfeksiyöz etkenlere bağlı bir hastalık izine rastlanılmamıştır ve kas ve sinir dokusunda harabiyet ile beyin dokusunda erime nekrozu saptanmıştır. Atomik absorpsiyon spektrofotometresi sonuçlarında selenyum miktarının olması gereken değerlerden çok düşük olduğu, ayrıca insan ve hayvanlara gıda yoluyla geçerek birikim zehirlenmesi yapabilen metal miktarlarının ise kabul edilebilir değerlerde oldukları saptanmıştır. Elde edilen tüm bulgulara göre Se ve E vitamini yetersizliğine bağlı yetersiz beslenme ile ilişkili bir sorun olabileceği kanısına varılmıştır. Hayvanların diyetlerine Selenyum ve E vitamini eklenmesine karar verilmiş ve reçete edilerek kullanılmaya başlanmıştır. Diyet değişikliğinin 3. gününden itibaren hasta hayvanlarda iyileşme başlamış ve 7. Günden itibaren tam iyileşme gözlemlenmiştir.

Anahtar Kelimeler: Civciv, Etiyoloji, Felç, Ölüm, Serbest Dolaşan, Selenyum.

\section{Etiological Investigation of Paralysis and Mortality in Free-Ranging Chicken, Turkey and Duck Chicks}

\begin{abstract}
In this study, the etiology of paralysis, nervous system disorders and deaths in chicken, duck and turkey chicks in a free-range poultry family enterprise was investigated. In the history of the disease, it has been reported that the neurological signs seen in the animals started on the 11th to 12 th days after the chicks came to the farm, and deaths occurred on the 2 nd to 3rd days. In order to determine
\end{abstract}

*Sorumlu Yazar: Bilge Kaan Tekelioğlu, ktekelioglu@cu.edu.tr 
the causes of death and for the etiological examination, 6 chickens, 12 ducks and 21 turkeys, which were paralyzed and near death situation, and feed samples were sent to our institution for investigation. Necropsies were performed on a total of 6 animals, one from each paralyzed and one dead animal from each animal group, and samples were taken from the feeds used. According to clinical symptoms and necropsy findings, poisoning, malnutrition and New Castle (ND) disease were suspected. Sampled kidney, liver, intestine, brain, lung and heart tissues were examined histopathologically and virologically, by RT-PCR. Atomic absorption spectrophotometer were used for feed analyzes. The amounts of copper $(\mathrm{Cu})$, zinc $(\mathrm{Zn})$, iron $(\mathrm{Fe})$, lead $(\mathrm{Pb})$, cadmium $(\mathrm{Cd})$, manganese $(\mathrm{Mn})$ and selenium (Se) were investigated in the feed samples. Conclusion; Viral RNA of New Castle disease virus (NDV) Avian Paramyxovirus Type-1 could not be detected by RT-PCR. In the histopathological examination, no traces of disease due to infectious agents were found and it was determined that there was destruction and degeneration in the muscle and nerve tissue and necrosis in the brain tissue. In the results of atomic absorption spectrophotometer, it has been determined that the amount of selenium is far below the required value, and the metal amounts that can cause accumulation poisoning by passing through food to humans and animals are at acceptable values. According to all the findings, it was concluded that the disease possibly related to the nutrition due to insufficiency of Se and vitamin E. It was decided to add selenium and vitamin $\mathrm{E}$ to the diets of animals and prescripted. From the 3rd day of the diet change, the sick animals started to heal and from the 7th day full recovery was observed.

Keywords: Chick, Etiology, Paralyse, Death, Fee-Range, Selenium.

\section{Giriş}

Dünya genelinde kanatlı eti üretimi 2015 yılında en çok üretilen et ürünü haline gelmiştir. 2019 yılında kanatlı eti üretimi 132 milyon tona ve yumurta üretimi 90 milyon tona ulaşarak dünya genelinde toplam et üretiminin yüzde 39'unu oluşturmuştur. Birleşmiş Millet Gıda Tarım Örgütü'nün (UNFAO) tahminlerine göre 2025 yılında toplam et üretimi miktarı 358,9 milyon tona ulaşırken, kanatlı eti üretimi miktarı ise 135,8 milyon tonla yüzde 37,8 paya ulaşarak dünya genelinde en çok üretilen et olma konumunu sürdüreceği beklenmektedir [1-5]. 2020 yilında Türkiye'de 19,8 milyar yumurta ve 2,2 milyon ton kanatlı eti üretildiği ve Türkiye'nin dünya çapında üretim büyüklüğü açısından 8 . sırada yer aldığı bildirilmiştir. 2020 yılı istatistik raporlarına göre Türkiye'de 19.788.063 tavuk yumurtası, 2.195.000 ton kanatlı eti üretilmiştir [3-5]. UN-FAO, serbest dolaşan kümes hayvanlarının gelişmekte olan ülkelerde kırsal hanelerde yaşayan ailelerin yaklaşık \%80'i tarafindan yetiştirildiğini bildirmiştir [1-2]. Türkiye genelinde yaklaşık 12 bin kanatlı işletmesi vardır ve sektör her yıl ortalama \%8 büyümektedir [3-6].

Newcastle hastalığ $(\mathrm{ND})$, Paramiksovirüs ailesinden Avian Paramyxovirus Tip-1 (APMV-1) virüsünün neden olduğu dünya genelinde yaygın olarak görülen ve evcil kümes hayvanları da dahil olmak üzere kuşları etkileyen, çok bulaşıcı ve genellikle şiddetli seyirli bir kanatlı hayvan hastalığıdır ve hastalığın etkeni Newcastle hastalığı virüsü olarak bilinmektedir (NDV). NDV potansiyel olarak evcil ve vahşi tüm kuş türlerini enfekte edebilir [7-11]. Uluslararası Virüs Taksonomisi Komitesi'nin (ICTV) son sinıflandırmasına göre NDV (APMV-1) Avian orthoavulavirus 1 türüne aittir [12-13]. Tüm NDV izolatları tek bir serotipe ait olmalarına rağmen genetik ve antijenik olarak çeşitlilik göstermektedir. Genetik farklılıklara dayalı olarak, NDV sınıf I ve sınıf II olarak sınıflandırılmaktadır. Sınıf II virüslerin evcil ve yabani kuşları kapsayan geniş bir kanatlı hayvan grubunu enfekte ettiği bilinmektedir [7-11, 13]. Hastalık hasta hayvanlarda hafif seyirli lentojenik, orta şiddette mezojenik veya çok virülent ya da egzotik Newcastle hastalığı olarak bilinen üç klinik formda görülür. En yaygın biçimi lentojenik suşların neden oldukları hafif seyirli enfeksiyonlardır ancak nadiren salgınlara neden olurlar. Hastalık genellikle solunum yollarını etkiler, ishal, depresyon, sinirsel belirtiler diğer önemli ve sık görülen bulgular arasında yer alırlar [7-11].

Kanatlı hayvanların yemlerinde birçok ağır metal eser element ve yem katk1 maddesi olarak kullanılmaktadır. Yem ve suyla yüksek seviyelerde alınan tüm mineral elementler hayvanlarda olumsuz etkiler yaratabilir, kensere ve toksikasyona neden olabilir. Esansiyel mineraller diyette yeterli optimum konsantrasyonlarda sağlanmalıdır. Hayvan yemlerinde bulunabilecek maksimum tolere edilebilir seviyeler için klavuzlar oluşturulmuştur. Gerek hayvan sağlı̆̆ hayvansal gıda olarak tüketen insanlar açısında metallerin yol açtığı birikim zehirlenmelerinin önlenmesi için bu rehberlere uyulmalıdır. Bu metaller çevremizde yaygın olarak bulunurlar, bunlardan bazıları (demir, bakır, manganez, çinko vb.) sağlık için gereklidir, ancak; diğer (arsenik, cıva, kurşun, kadmiyum, vb) zehirli ve sağlığa zararlıdır. Tehlikeli atık toplama alanlarından ve diğer endüstriyel kirlilik türlerinden ve belediye atıklarından dolayı kirlenmiş yeraltı suyu sistemleri muhtemelen en önemli toksikasyon kaynaklarıdır [14-16]. Metallerden Kurşun $(\mathrm{Pb})$; zehirlenme serebral ödem ve nöronal hasara, demiyelinizasyona ve ölüme [17], Çinko (Zn); zehirlenme, kas harabiyeti, inkoordinasyon, yürüyememe, ishal ve ölüme, Kadmiyum (Cd); sinir ve solunum sistemi hastalıklarına, böbrekler ile kemik dokularda hasara [18], Mangan (Mn); nörolojik bozukluklara yol açabilir [14-18]. Kanatlı hayvanlarda E vitamini kuvvetli bir antioksidandır ve çok önemli işlevleri vardır. Başlıca sinir sisteminin gelişimi ve sağlıklı faaliyetleri, iskelet ve kas gelişimi ile kas distrofisinin engellenmesi ve dolaşımın düzenlenmesini ve sağlıklı işleyişlerini sağlar. Sperm canlılığ1 ve yumurta verimini arttırarak üreme faaliyetlerinin sağlıklı olmasını sağlar ve döl tutma potansiyelini arttırır. Etkin bir bağ 1 şılık geliştiricisi ve düzenleyicisi olarak viral, bakteriyel, paraziter ve mikotik hastalıklara karşı direnç artışı sağlar. Sıcak ve soğuk stresine karşı direnci arttırarak verimi yükseltir. E vitamini eksikliği ise başta Beyaz Kas Hastalığı olmak üzere yukarıda sayılan tüm sistem ve işlevlerde bozulmalara yol açar [19]. Selenyum (Se) kuvvetli bir antioksidandır ve bir eser elementtir. Genellikle üreme fonksiyonlarının normal olarak sürdürülebilmesi için ek olarak hayvanların diyetine eklenir ve diyetteki selenyum eksikliği insanlarda, kanatlı ve çiftlik hayvanları ile laboratuvar hayvanlarında sperm konsantrasyonunda, sperm hareketliliğinde ve sperm kapasitesinde azalmaya neden olur [19-21]. E vitamin ve Se eksikliği birlikte görüldüğü takdirde hepatitis ve karaciğer fonksyon bozuklukları, beyin ve beyincikde erime nekrozları ile gelişen ensefalomalasi, civcivlerde deri altı doku ödemi ve hafif kanamalrla birlikte gelişen eksüdatif diyatez ve en önemlisi beyaz kas hastalığı görülür [19-21].

Kümes hayvanlarının büyümesi çoğunlukla verilen yemlere bağlıdır ve yemler ağır metaller de dahil olmak üzere farklı kirleticiler içerebilmektedir. Metaller, Bakır $(\mathrm{Cu})$, Çinko $(\mathrm{Zn})$, 
Demir (Fe), Kurşun ( $\mathrm{Pb}$ ), Kadmiyum (Cd), Mangan (Mn) ve Selenyum (Se) miktarları tayini hem hayvansal doku ve organlardan hem de yemlerden atomik absorpsiyon spektrometrisi teknikleri kullanılarak yapılabilmektedir [22,23].

$\mathrm{Bu}$ çalışmada Çukurova Üniversitesi Ceyhan Veteriner Fakültesine, bir serbest dolaşan (salma ya da gezen) kanatlı hayvan aile işletmesinden gönderilen felçli ve ölüme yakın halde olan 6 tavuk, 12 ördek ve 21 hindi yavrusu ile yem örnekleri incelenmiştir. Hasta hayvanlarda görülen felç, sinir sistemi bozuklukları ve ölümlerin etiyolojisi multidispliner bir çalışma ile araştırılmıştır. Hasta ve ölen hayvanlar virolojik ve histopatolojik yöntemlerle ve yem örnekleri de atomik absorpsiyon spektrometrisi teknikleri ile incelenmiştir.

\section{Materyal ve Metot}

\subsection{Real Time PCR (RT-PCR) ile Virolojik Teşhis}

\subsubsection{RNA Ekstraksiyonu ve Reverse Transkripsiyon}

Felçli ve ölüme yakın halde olan 6 tavuk, 12 ördek ve 21 hindi yavrusundan orofaringeal ve kloakal sürüntüler topland. Felçli ve ölen hayvanlardan 1'er adet olmak üzere toplam 6 hayvandan nekropsi ile incelenmek üzere alınan böbrek, karaciğer, bağırsak, beyin, akciğer ve kalp dokularından elde edilen marazi maddeler her bir hayvan için bir araya getirilerek iyice ezildi, vortex ile $3000 \mathrm{rpm} / 3 \mathrm{dk}$ karştırıldı ve doku havuzu oluşturularak incelendi.

Her bir hayvan grubu için ayrı ayrı olarak orofaringeal ve kloakal örneklerden oluşan ve 3 'er hayvandan oluşan sürntü örnek grupları oluşturuldu ( 2 tavuk, 4 ördek ve 7 hindi örnek havuzu). $500 \mu 1$ nükleaz içermeyen su eklendikten sonra tüpler ayrı ayrı vortekslendi. Daha sonra her bir örnekden $100 \mu \mathrm{l}$ alınarak toplam hacim $300 \mu$ l olacak şekilde bir tüp içerisinde birleştirilerek örnek havuzları oluşturuldu ve son olarak $140 \mu 1$ numune her bir havuzdan alındı.

Orofaringeal ve kloakal sürüntü örnekleri QIAmp Viral RNA Mini Kit (Qiagen $\left.{ }^{\circledR}\right)$ ve doku havuzu örnekleri için RNeasy mini kit (Qiagen $\circledast$ ) kullanılarak RNA ekstraksiyonları yapıldı. Qiagen one-step RT-PCR hazır kiti kullanılarak RNA ters transkripsiyona (reverse transcription) tabi tutuldu ve cDNA üretimi sağlandı. Tüm çalışmalarda üretici tarafından kullanım klavuzunda açıklandığg şekilde talimatlara uyularak çalışıldı.

\subsubsection{Newcastle Hastalığı Virüsü İçin Real Time (RT- PCR) Testi}

Tüm numuneler NDV'nin matrix geni için gerçek zamanlı RT-PCR testleri ile analiz edildi. Kullanılan primerler ve problar NDV-RNA'yı saptamak daha önce tarif edildiği şekilde kullanıldı [24]. RT-PCR optimizasyonu için yapılan testlerde, pozitif kontroller kullanılırken $4 \mu \mathrm{l}$ cDNA ile $10 \mathrm{pmol} / \mu \mathrm{l}$ konsantrasyonu içeren $F$ ve $R$ primerleri kullanıldığında optimal amplifikasyon sinyalleri elde edildiği saptandı.

Optimize edilmiş gerçek zamanlı RT-PCR reaksiyonu 25 $\mu$ l'lik bir karışımdan oluşuyordu; 12,5 $\mu$ l qPCR Master Mix (Thermo Scientific), 1,25 $\mu$ l forward primer (10 pMol / $\mu \mathrm{l}), 1,25$ $\mu \mathrm{l}$ reverse primer $(10 \mathrm{pMol} / \mu \mathrm{l}), 0,4 \mu \mathrm{l}$ prob $(10 \mathrm{pMol} / \mu \mathrm{l}), 2,5$ $\mu \mathrm{l}$ cDNA ve $7,1 \mu \mathrm{l}$ nükleaz içermeyen su. Test karışımı bir termal döngüleyiciye yerleştirildi (Biorad, Chromo-4) ve 10 dakika boyunca $95^{\circ} \mathrm{CC}^{\prime} \mathrm{de}$ inkübasyonla polimeraz aktive edildi. Termal döngüleyici koşulları 40 döngü için $95^{\circ} \mathrm{C}$ 'de $15 \mathrm{~s}$ denaturasyon, $52^{\circ} \mathrm{C}$ 'de $30 \mathrm{~s}$ primerlerin açılan DNA zincirlerine yapışması (annealing) evresi ve $72^{\circ} \mathrm{C}$ 'de $10 \mathrm{~s}$ primer uzaması evresi (extension) olarak uyguland. Tüm PCR reaksiyonları için Negatif kontrol olarak nükleaz içermeyen su kullanıldı. LA Sota Live aşı suşu şablon ve NDV'ye özgü Pozitif kontrol RNA olarak kullanıldı.

\subsection{Histopatoloji}

Felçli ve ölen hayvanlardan 1'er adet olmak üzere toplam 6 hayvana nekropsi yapılmış ve incelenmek üzere böbrek, karaciğer, bağırsak, beyin, akciğer ve kalp dokularından marazi maddeler alındı. Doku örnekleri histopatolojik olarak incelendi. $\mathrm{Bu}$ amaçla numuneler \%10 nötr tamponlu formalin, parafin bloklara gömüldü, daha sonra 4-5 $\mu$ m'ye kesildi ve hematoksilen ve eozin (HE) ile boyand. Elde edilen kesitler 1 şı mikroskobunda Objektif Lens 20X0,40, Büyütme X 10 'da incelendi.

\subsection{Atomik Absorbsiyon Spektrometresi ile Yemlerde Metal Analizi}

\subsubsection{Yaş Yakma}

Yem örneklerinde Bakır (Cu), Çinko $(\mathrm{Zn})$, Demir $(\mathrm{Fe})$, Kurşun (Pb), Kadmiyum (Cd), Mangan (Mn) ve Selenyum (Se) miktarları araştırıldı. Hasta hayvanlar ile birlikte gönderilen yem örnekleri kurutuldu. Kurutulan örnekler agat değirmeninde öğütülerek analize hazır duruma getirildi. Öğütülmüş örneklerden 0,5 gr tartılarak yaş yakma yapıldı. Yaş yakma işlemi mikro dalga fırınında (CEM marka) yakılmak üzere, teflon tüplere 0,5 gr örnek tartılıp üzerine $2 \mathrm{ml} \mathrm{H} 2 \mathrm{O} 2$ ve $5 \mathrm{ml}$ HNO3 asit karışımı ilave edilerek 40 dakika yakma işlemine maruz bırakılarak tamamlandı. Yakma işlemi biten örneklerin son hacimleri $20 \mathrm{ml}$ olacak şekilde saf su ile tamamlanıp mavi bant filtre kâğıdından süzülerek analize hazır hale getirildi.

\subsubsection{Elementlerin Tayini}

Analize hazır hale getirilen örneklerden Atomik Absorbsiyon Spektrometresi kullanılarak Bakır $(\mathrm{Cu})$, Çinko $(\mathrm{Zn})$, Demir (Fe), Kurşun (Pb), Kadmiyum (Cd), Mangan (Mn) ve Selenyum (Se) elementlerinin miktarları tayin edildi. $\mathrm{Bu}$ analizlerde Analatik Jena - ContrAA 700 (AAS) cihazının grafit ünitesi kullanıldı. ContraAA 700 (AAS) cihazı ile analizi yapılacak olan metaller için standartlar hazırlanıp metalin absorbans yaptığı dalga boyunda okuma yapılarak standart eğrisi hazırlandı. Bu standart eğrisi yardımıyla örneklerde bulunun eser miktardaki metaller tayin edildi.

\section{Araştırma Sonuçları ve Tartışma}

\subsection{Real Time PCR (RT-PCR) ile Virolojik Teşhis Bulguları}

İncelenen doku, orofaringeal ve kloaka örneklerinin hiçbirisinde Newcastle hastalığı virüsüne ait RNA saptanamamıştır.

\subsection{Histopatoloji Bulguları}

Nekropside, makroskobik olarak civcivde daha belirgin olmak üzere; beyin ve beyincikte ödem ve hiperemi saptand. Hem civciv, hem de ördekte beyinciğin yumuşak ve peltemsi kıvamda olduğu görüldü. 
Mikroskobik incelemede; beyinde ve beyincikte daha belirgin ve yaygın hiperemi ile birlikte yer yer kanama alanları saptand. Yine beyin ve beyincikte daha belirgin olan yaygin demyelinizasyon, spongiöz görünüm ve nöyronal dejenerasyon saptandı (Şekil 1A,1B,1C,1D). Karaciğerde yaygın ve belirgin hiperemi, parankim dejenerasyonu, böbreklerde hiperemi, tubul epitellerinde granuler dejenerasyon saptandı (Şekil 2).

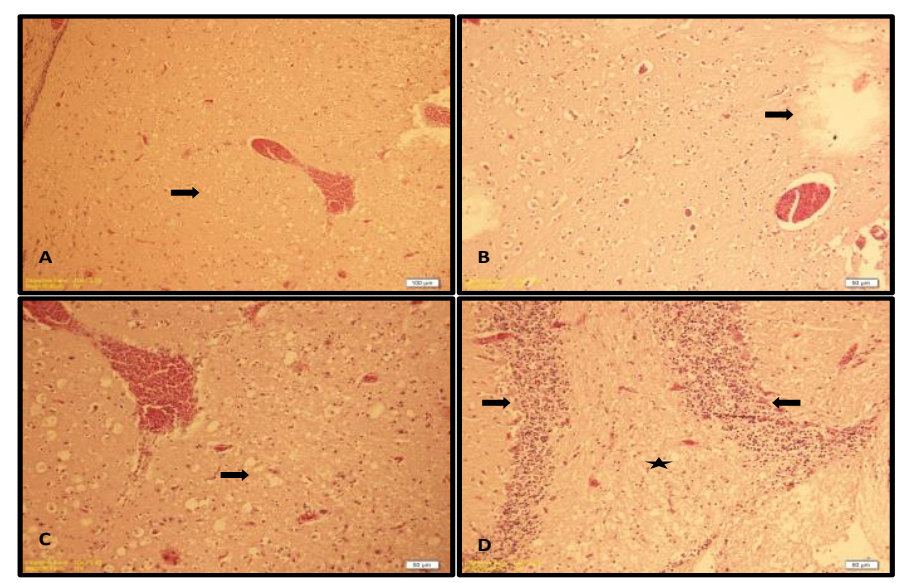

Şekil 1A: Hiperemi ve demyelinizasyon (ok). Beyin. H\&E.

Şekil 1B: Hiperemi, demyelinizasyon ve liquifikasyon (ok). Beyin. H\&E

Şekil 1C: Hiperemi, demyelinizasyon (ok). Beyin. H\&E.

Şekil 1D: Neuropilde demyelinizasyon (yıldız) ve purkinje hücrelerinde dejenerasyon (oklar). Beyincik. H\&E.

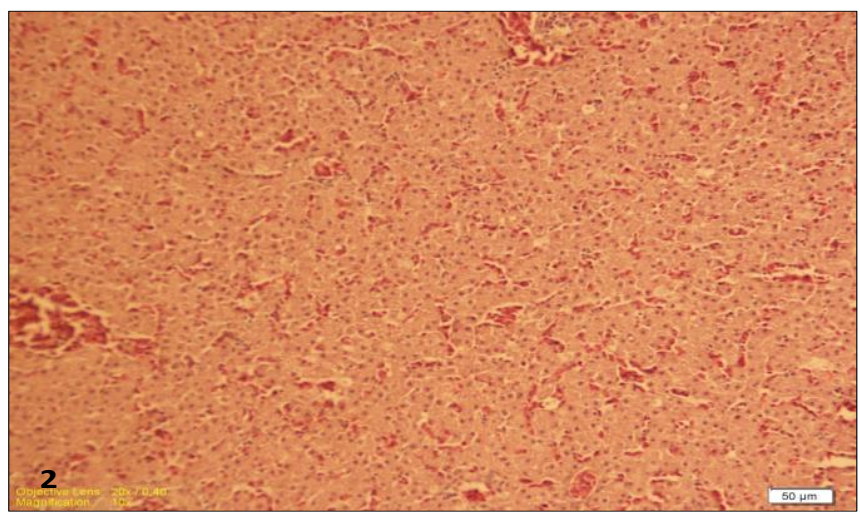

Şekil 2: Karaciğerde yaygın hiperemi ve parankim dejenerasyonu. H\&E.

\subsection{Atomik Absorbsiyon Spektrometresi ile Yemlerde Metal Analizi}

Yem numunelerinden alınan örneklerde Bakır $(\mathrm{Cu})$, Çinko $(\mathrm{Zn})$, Demir (Fe), Kurşun ( $\mathrm{Pb}$ ), Kadmiyum (Cd), Mangan (Mn) ve Selenyum (Se) miktarları tayin edildi ve elde edilen bulgular Tablo 1' de verildi.

Tablo 1. Yem Örneği Analiz Sonuçlarl; Cu324, Mn279, Fe248, Zn213 mg. $\mathrm{kg}^{-1}$, Cd, Pb ve Se $\mu \mathrm{g} . \mathrm{kg}^{-1}$ olarak ölçülmü̈şür.

\begin{tabular}{|c|c|c|c|c|c|c|}
\hline Cu324 & Mn279 & Fe248 & Zn213 & Cd & Pb & Se \\
\hline 0,9 & 1,895 & 3,670 & 6,115 & 50,25 & 224,9 & 1,23 \\
\hline
\end{tabular}

Newcastle hastalığı, Epidemik Tremor Hastalığı, Marek Hastalığı, Botulismus, Selenyum ve E vitamini eksikliği, zehirlenmeler ve metal zehirlenmeleri kanatlı hayvanlarda sinir e-ISSN: 2148-2683 sistemi bozukluklarına, felç ve ölüme neden olabilmektedir. Bunlar arasında Newcastle hastalığı (NDV, APMV-1), Epidemik tremor (Tremovirüs A, Tremovirüs B) ve Marek hastalığı (Marek Disease Virus, MDV) viral enfeksiyonlardır. Selenyum ve E vitamini eksikliği genellikle rasyon yetersizliğine bağlı beslenme bozukluları sonucu ortaya çıkmaktadır. Diğerleri ise kontamine gıda ve su alımı ile ortaya çıkmaktadır ve ilave olarak Botulismusda kontamine leş karkaslar, sinekler ve kurtçukların gagalanaması ile bulaşma oluşmaktadır. Hastalıktan etkilenen hayvanlarda titreme ve kas güçsüzlükleri gözlemlenir. Ayakta duramadıkları için yatarlar. Acı çekiyormuş gibi zorlukla yürürler. Boyunları bir yana çevrilmiş veya bükülmüş pozisyondadır. Havaya bakıp nerede olduklarının farkında değilmiş gibi şuur kayıpları gözlemlenir.

$\mathrm{Bu}$ çalışmada ayırıcı tanı için yapılan virolojik, histopatolojik ve yem muayenesi çalışmaları sonrası klinik ve laboratuvar bulgularının uyumluluğuna ve hastalığın gelişimine ve hasta sahibinden alınan anamnez bilgilerine dayanarak Marek Hastalığı, Epidemik Tremor Hastalığı ve Botulismus elemine edilmiştir.

Epidemik Tremor Hastalığı etkenleri Tremovirüs A ve Tremovirüs B virüsleridir ve Avian Ensefalomyelit olarakda bilinmektedir. Virüs enfekte yetişkin tavukların dışkılarında bulunur ve saçılır. Sağlıklı hayvanlar, dışkı ile kontamine olmuş yem veya su ile enfekte olurlar. Virüs yetişkin tavuklardan civcivlerine de geçer. Civcivlerin enfekte olmasının en önemli yolu budur. Enfekte tavuklar normalden daha az yumurta üretir ve enfekte yumurtalardan çıkan civcivler, genellikle 5 ila 7 günlükken sinir belirtileri gösterir. Yetişkin tavuklarda ölümler gözlenebilir [23]. Oysaki çalışmada incelenen hasta hayvanlar arasında felç ve ölümler 11-12. günlerde görülmeye başlamış ve yetişkin hayvanlarda yumurta üretiminde azalma ve ölüm dahil olmak üzere bir sağlık problemi gözlemlenmemiştir. Histopatolojik bulgularda beyin ve beyin dokuslarında viral ensefalomyelit bulgularına rastlanılmamıştır ve hastalık elemine edilmiştir.

Marek Hastalığı (MD) etkeni Marek Disease Virus (MDV) veya Gallid alphaherpesvirus-2 (GaHV-2)'dir. Hastalıktan etkilenen hayvanların bir veya iki bacağı veya kanatları felç olur ve yatarlar. Normal bir şekilde yem yerler ama önemli ölçüde kilo kaybı oluşur. Ölümler görülebilir. Hasta hayvan karkasları kaşektiktirler. Periferal sinirler normalde ince ve fildişi beyazı olması gerekirken hasta hayvanlarda kalınlaşmı ve sarı-kahve renktedirler. Klasik formda periferik sinirler etkilenir ve bu hastalık için karakteristik olan asimetrik paralizle bir bacağın öne diğer bacağın geriye doğru uzatılması ile karakterize oturuş biçimi 'Balerin Duruşu' pozisyonu görülür ve kanatların bir ucu yere doğru uzar ve boyun bir yana doğru bükülür. Nervous vagusun etkilenmesi ile zolunum güçlüğü gözlemlenir. Akut Marek hastalığında genellikle 4-8 haftlık hayvanlar etkilenir ve $\% 80$ ' e ulaşan ölümler görülebilir. Oküler lymfomatosisde göz lezyonları vardır ve iris yeşil renge döner. Kutanöz form ise tüy foliküllerini etkiler [24-25]. Marek hastalığı tavukların dışındaki kanatlı hayvanlarda nadiren bildirilmiştir ve hindilerde bulunan MDV hindileri hastalandırmaz ve MD'den korunmada aşı suşu olarak kullanılmaktadır. Oysaki çalışmada incelenen hasta hayvanlar tavuk, hindi ve ördeklerden oluşmakta olup aralarında en çok etkilenenlerin hindiler olduğu gözlemlenmiştir [24-25]. Klinik ve histopatolojik bulgular özellikle periferal sinirlerin normal yapıda oluşları ve hastalıkla ilişsili diğer patolojik bulguların eksikliği nedeniyle hastalık elemine edilmiştir. 
RT-PCR testi Newcastle hastalığı tanısnda hassas bir test yöntemi olarak kabul edilmektedir [7,8,10,11]. İncelenen doku, orofaringeal ve kloaka örneklerinin hiçbirisinde Newcastle hastalığ 1 virüsüne ait RNA saptanamamıştır ve hastalık elimine edilmiştir.

Clostridium botulinum tarafından üretilen bir toksin botulizme neden olur. Bu toksin genellikle ölü ve çürüyen kümes hayvanları ve diğer karkaslarda bulunur. Bu karkaslarla beslenen kurtçuklarda veya böceklerde de bulunabilir. Tavuklar bu leşleri, kurtçukları veya böcekleri gagaladıklarında, su içtiklerinde veya leşle kontamine yem yediklerinde hastalanırlar [26]. Oysaki kümeste ölü karkas, aşırı sinek ve larva olmayışı ile Botulismus ve 11-12 günlük civcivler dışında aynı suyu içen hayvanlarda bir sağlık sorunu olmayışı ile zehirlenme elimine edilmiştir.

Kümes hayvanlarının beslenmesi ve büyümesi yemlere bağlıdır. Her ne kadar salma ya da gezen tavuklar doğadan da beslenselerde aldıkları besin yetersiz kalmaktadır ve mutlaka takviye yem ihtiyacı bulunmaktadır. Özellikle sınırlandırılmış alanda kalabalı besicilik yapıldığında beslenmenin yemleme ile yapılması gerekmektedir. Kanatlı hayvan yemlerinde Kurşun ve Krom gibi ağır metaller de dahil olmak üzere farklı kirleticiler bulunabildiği bildirilmiştir [14-16, 17]. Ayrıca tüm mineraller, büyük miktarlarda tüketildiğinde hayvanlarda toksikoza neden olabilmektedir. Kanatlı yemlerinde birçok ağır metal eser element ve yem katkı maddesi olarak kullanılmaktadır. Bu metaller çevremizde yaygın olarak bulunurlar, bunlardan bazıları (demir, bakır, manganez, çinko vb.) sağlık için gereklidir, ancak; diğer (Arsenik, cıva, kurşun, kadmiyum, vb) zehirli ve sağlığa zararlıdır [15]. WHO/FAO tarafından belirtildiği şekilde 0,05 ve 0,1 ppm. Kurşun $(\mathrm{Pb})$ ve Krom (Cr) metalleri, kümes hayvanlarının büyümesine neden olabilir, ancak konsantrasyonlar izin verilen sınırları aşarsa toksik hale gelebilirler. Aşırı miktarda metal alımı hayvanlar tarafından insan vücuduna yollarını bulmak, insan sağlığına çok zararlı olduğu bildirilmiştir [14-16, 20]. Tablo 2'de analiz yapılan metal elementlerinin ölçülen değerleri ile tolere edilebilen maksimum limitler verilmiştir [20,27].

Shamshad vd., (2017) Lahore, Pakistan'da yaptıkları bir çalışmada yem numunelerinde saptadıkları Kurşun miktarlarının $0,846 \mathrm{mg} / \mathrm{kg}$ ortalama değer ile Avrupa Birliği’nin kabul ettiği maksimum sınır değer olan $0,1 \mathrm{mg} / \mathrm{kg}$ değerinin çok üzerinde olduğunu ve takip edilmesi gerektiğini bildirmişlerdir. Dahri vd., (2019) yaptıkları Haydarabad, Hindistan'da yaptıkları bir çalışmada kanatlı hayvan yemlerinde 0,05 ppm Kurşun ve 0,01 ppm Krom miktarları saptadıklarını ve bu değerlerin WHO/FAO referans değerlerinin üzerinde olduğunu bildirmişlerdir. Kurşun vücutta birikim yapmasının yanı sıra başlıca kalp ve damar hastalıkları ile böbrek yetmezliği gibi önemli sağlık problemlerine yol açmaktadır. Kurşun zehirlenmesinin tüm Dünya genelinde alarm verici düzeyde olduğu kabul edilmektedir [20]. Çalışmamızda elde edilen veriler yemde saptanan kurşun değerlerinin $0,2224 \mu \mathrm{g} . \mathrm{kg}^{-1}$ ile kabul edilebilir limitlerde olduğu saptanmıştır.
Tablo 2. Test edilen metal elementlerinin atomik absorsorpsiyon tekniği ile ölçülen değerleri ve tolere edilebilen maksimum limitler.

\begin{tabular}{|c|c|c|}
\hline $\begin{array}{c}\text { METAL } \\
\text { ELEMENTI }\end{array}$ & BULGULAR & $\begin{array}{c}\text { TOLERE EDILEN } \\
\text { MAKSIMUM LIMIT }\end{array}$ \\
\hline Bakır $(\mathrm{Cu})$ & $0,9 \mathrm{mg} / \mathrm{kg}^{-1}$ & $3 \mathrm{mg} / \mathrm{kg}^{-1}$ \\
\hline Çinko $(\mathrm{Zn})$ & $\begin{array}{c}6,115 \mathrm{mg} / \mathrm{kg}^{-} \\
1\end{array}$ & $20 \mathrm{mg} / \mathrm{kg}^{-1}$ \\
\hline Demir $(\mathrm{Fe})$ & $\begin{array}{c}3,670 \mathrm{mg} / \mathrm{kg}^{-} \\
1\end{array}$ & $500 \mathrm{mg} / \mathrm{kg}^{-1}$ \\
\hline Kadmiyum $(\mathrm{Cd})$ & $50,25 \mu g \cdot \mathrm{kg}^{-1}$ & $0,5 \mathrm{mg} / \mathrm{kg}^{-1}$ \\
\hline Kurşun $(\mathrm{Pb})$ & $\begin{array}{c}0,2224 \mu g \cdot \mathrm{kg}^{-} \\
1\end{array}$ & $0,3 \mathrm{mg} / \mathrm{kg}^{-1}$ \\
\hline Mangan $(\mathrm{Mn})$ & $\begin{array}{c}1,895 \mathrm{mg} / \mathrm{kg}^{-} \\
1\end{array}$ & $4800 \mathrm{ppm}$ \\
\hline Selenyum $(\mathrm{Se})$ & $1,23 \mu \mathrm{g} \cdot \mathrm{kg}^{-1}$ & $5-20 \mathrm{ppm}$ \\
\hline
\end{tabular}

Tayeb ve Qader (2012) yaptıkları çalışmada, Broiler yemlerine $0.45 \mathrm{mg} \mathrm{Se}+100 \mathrm{mg} \mathrm{VitE} / \mathrm{kg}$ eklendiğinde büyüme performansı ve hematolojik verilerin iyileştiğini saptadıklarını açıklamışlardır. Tavuk civcivleri genellikle bir kilogram yem içerisinde $450 \mathrm{IU}$ ila $900 \mathrm{IU}$ oranlarında $\mathrm{E}$ vitaminini iyi tolere edebilmektedir [28]. Bir yumurta tavuğu, yumurta üretimini sürdürmek için günlük diyetlerinde 0,06 ppm selenyuma ihtiyaç duymaktadır. Etlik piliç yetiştiriciliğinde ise günlük selenyum miktarının 0,2-0,3 ppm. seviyelerinde olması gerektiği önerilmektedir [29]. Fischer vd., (2008) hindilerin optimum büyüme performansını yakalayabilmeleri için günlük $0.30 \mathrm{mg}$ $\mathrm{Se} / \mathrm{kg}$ miktarını yemle almaları gerektiğini bildirmişlerdir. Çalışmada elde ettiğimiz bulgular hayvanların yemlerindeki Selenyum miktarının 1,23 $\mu \mathrm{g} \cdot \mathrm{kg}^{-1}$ ile olması gerekenin altında olduğunu ve Se eksikliğine bağlı sağlı problemleri yaratabileceğini göstermiştir. Farklı kanatlı hayvan türlerinin Se ihtiyaçlarının farklı olduğu ve yemde Se miktarının hindilerde $0.264 \mathrm{mg} / \mathrm{kg}$ ve tavuk cicvcivlerinde $0.154 \mathrm{mg} / \mathrm{kg}$ olmas1 gerektiği kabul edilmektedir [33]. Broiler tavuk civcivlerine 5 hafta yaşına kadar ve yumurtacı civcivlere ve hindi palazlarına ise 8 haftalı olana kadar kadar selenyum takviyesi uygulanabileceği belirtilmiştir [34]. Farklı ırklardan oluşan karma sürülerde yem kompoziyonunun tüm irkları kapsayacak şekilde hazırlanması önemli bulunmuştur ve bu çalışmada hastalığın hindiler arasında daha fazla görülmesinin ana nedeninin olabileceği kanısına varılmıştır.

\section{Sonuç}

Hasta hayvanların muayenesi ile elde edilen klinik bulgular, hasta sahibinden alınan anamnez ve virolojik test sonuçları, nekropsi ve histopatolojik inceleme sonuçları bir arada değerlendirildiğinde organlarda gözlemlenen makroskobik bulgulara göre enfeksiyöz etkenlere bağlı bir hastalık izine rastlanılmamıştır. Bulguların Vitamin E ve Selenyum yetersizliğine bağlı olabileceği düşünülmüş ve bu yönlü araştırma ve tedavi önerilmiştir. Hayvanların diyetlerine Selenyum ve E vitamini eklenmesine karar verilmiş ve reçete edilerek kullanılmaya başlanmıştır. Diyet değişikliğinin başlamasıyla birlikte yeni hasta hayvan görülmemiş, 3 . gününden itibaren hasta hayvanlarda iyileşme başlamış ve 7 . günden itibaren tam iyileşme gözlemlenmiştir.

Kümes hayvanları tüm dünyada en fazla üretilen ve tüketilen et ürünü konumuna geçmiş önemli bir protein kaynağıdır ve dünya genelinde üretimi ve tüketimi sürekli artış 
göstermektedir. Kanatlı endüstrisinde, enfeksiyonlar, beslenme yetersizliği ve çevresel faktörler başta olmak üzere hayvan sağlığını ve verimini olumsuz etkileyen etkenlerin kontrolü ve yüksek biyogüvenli tedbirleri ile uygulamaları sağlıklı gıda üretimi ve küçük aile işletmelerinin sürdürülebilirliği açısından büyük önem taşımaktadır. Bu çalışma hızlı reaksiyon gösterilen multidispliner bir çalışma sonrası hayvan sağlığının korunmasına ve etiyolojik tanı ile ana sorunun çözülmesinin sürdürebilir hayvancılık ve sürü sağlığı açısından ne kadar önemli olduğunu ortaya koyması açısından önemli veriler içermektedir. Ayrıca insan ve hayvanlara gıdalar yoluyla geçebilen ve birikim zehirlenmelerine yol açabilen metallerin bulunamamış olması gıda güvenilirliği açısından önemlidir.

\section{Teşekkür}

$\mathrm{Bu}$ çalışma kısmen Çukurova Üniversitesi BAP birimi tarafından desteklenmiştir, teşekkür ederiz. Çalışmanın ön bulgularını içeren 'Abstract' 10-13. Kasım 2016 tarihinde Yakın Doğu Üniversitesi, Kuzey Kıbrıs Türk Cumhuriyetinde düzenlenen "Uluslararası Hayvansal Gidalar Kongresi'nde" sunulmuştur.

\section{Kaynakça}

FAO (2021) ${ }^{\mathrm{a}}$. Meat market review. http://www.fao.org/3/cb 3700en/cb3700en.pdf. Erişim Tarihi: 25.11.2021

FAO (2021) ${ }^{\mathrm{b}}$. Poultry production. http://www.fao.org/poultryproduction-products/production. Erişim Tarihi: 25.11.2021

Turkish White Meat Production (Türkiye Beyaz Et Sektörü). https://www.zmo.org.tr/resimler/ekler/d24d7c78bb96fc2_ek. pdf Accessed 10.07.2021. Erişim Tarihi: 25.11.2021

Poultry Sector in Turkey (Türkiye'de kanatlı sektörü). http://www.turktarim.gov.tr/Haber/401/turkiyede-kanatlisektoru-her-yil-yuzde-8-buyuyor. Erişim Tarihi: 25.11.2021

Turkish Statistical Agency Report on Poultry (Türkiye İstatistik Kurumu Raporu). https://data.tuik.gov.tr/Search/ Search?text=tavuk. Erişim Tarihi: 25.11 .2021

Sogut, M., \& Tekelioglu, B.K. (2021). Avian Herpesviruses And Their Potential Impacts On Poultry Health. XII International Scientific Agriculture Symposium "AGROSYM 2021", Jahorina, Bosnia and Herzegovina, 1189-1195.

Turan, N., Ozsemir, C., Yilmaz, A., Çizmecigil, U.Y., Bamac, O.E., Gurel, A., Kutukcu, A., Ozsemir, K., Tali, E.H., Yilmaz, S.G., Yaramanoglu, M., Tekelioglu, B.K., Ozsoy, S., Richt, J.A., Iqbal, M., \& Yilmaz, H. (2020). Identification of Newcastle disease virus subgenotype VII.2 in wild birds in Turkey. BMC Vet Res, 16, 277. https://doi.org/10.1186/ s12917-020-02503-3

Newcastle Disease. OIE 2021. https://www.oie.int/en/disease/ newcastle-disease/. Erişim Tarihi: 25.11.2021

Murphy, A.F., Gibbs, E.P.J., Horzinek, M.C., \& Studdert, M.J. (1999). Veterinary Virology, Third Edition. Boston New York Sydney Tokyo Toronto, Elsevier.

Alexander, D. J., Aldous, E.W. \& Fuller, C.H. (2012) The long view: a selective review of 40 years of Newcastle disease research, Avian Pathology, 41:4, 329-335, DOI: 10.1080/ 03 079457.2012.697991

Dzogbema, K. F-X., Talaki, E., Batawui, B.K., \& Dao, B.B. (2021). Review on Newcastle disease in poultry. AJOL, 15:2, 773-790, DOI: 10.4314/ijbcs.v15i2.29

ICTV (2020). Virus Taxonomy 2020 Release. releasehttps: //talk.ictvonline.org/ictv-reports/ictv_online_report/negative -sense-rna-viruses/w/paramyxoviridae/1193/genusorthoavulavirus

Ferreira, H.L., Taylor, T.L., Dimitrov, K.M., Sabra, M., Afonso, C.L., \& Suarez, D.L. (2019) Virulent Newcastle disease viruses from chicken origin are more pathogenic and transmissible to chickens than viruses normally maintained in wild birds. Vet Microbiol.;235:25-34

Senthilkumar, T.S.S., Muralidharan, K.D.J., Sasikumar, P., \& Muthusamy, N. (2016). Metal Toxicosis In Poultry - A Review. International Journal of Science, Environment and Technology, Vol. 5(2), 515 - 524.

Jadhav, S.H., Sarkar, S.N., Patil, R.D., \& Tripathi, H.C. (2007). Effects of subchronic exposure via drinking water to a mixture of eight water contaminating metals: a biochemical and histopathological study in male rats. Arch Environ Contam Toxicol, 53: 667-677.

Henry, P. R., \& R. D. Miles. (2001). 'Heavy metals - vanadium in poultry' Ciência animal brasileira 2(1): 11-26.

Khan, M.S.H., Mostofa, M., Jahan, M.S., Sayed, M.A., \& Hossain, M.A. (2008). Effect of garlic and vitamin-B complex in lead acetate induced toxicities in mice. Bangladesh Journal of Veterinary Medicine, 6(2): 203-210.

Idrissa, S., Pitala, W., Gnandi, K., \& Oke, E. (2020). Physicochemical Quality and Heavy Metals Contamination of Drinking Water Used in Poultry Farms at Maritime Region of Togo. American Journal of Biological and Environmental Statistics, 6, 43. DOI:10.11648/j.ajbes.2020 0603.12.

Rengaraj, D., \& Hong, Y. H. (2015). Effects of dietary vitamin E on fertility functions in poultry species. International journal of molecular sciences, 16(5), 9910-9921. https://doi.org/10.3390/ijms 16059910

Young, V.R., Nahapetian, A., Janghorbani, M. (1982). Selenium bioavailability with reference to human-nutrition. Am. J. Clin. Nutr, 35, 1076-1088.

Hansen, J.C., Deguchi, Y. (1996) Selenium and fertility in animals and man-A review. Acta Vet. Scand, 37, 19-30.

Shamshad, J., Najeeb, J., Naeem, M.A., \& Nawaz, C., M. (2017). Simultaneous Atomic Absorption Spectroscopic Quantization Survey of Toxic Metals in Poultry Feed and Their Translocation in Various Tissues of Chicken in Lahore Region of Pakistan. International Journal of Scientific \& Engineering Research, 8(4), 791-798.

Dahri, S.N., Pathan, A., Balouch, A., \& Mallah, S. (2020). Assessment of Heavy Metals in Poultry Feed of Hyderabad, Sindh. 2nd International Conference on Sustainable Development in Civil Engineering, MUET, Pakistan,284289.

Wise, M. G., Suarez, D. L., Seal, B. S., Pedersen, J. C., Senne, D. A., King, D. J., Kapczynski, D. R., \& Spackman, E. (2004). Development of a real-time reverse-transcription PCR for detection of newcastle disease virus RNA in clinical samples. Journal of clinical microbiology, 42(1), 329-338. https://doi.org/10.1128/JCM.42.1.329-338.2004

Abdul- Aziz, T., (2019). Avian Encephalomyelitis. MSD Veterinary Manuel. https://east.msdvetmanual.com/poultry/ avian-encephalomyelitis/avian-encephalomyelitis. Erişim Tarihi: 24.11.2021.

Aksoy, E. (1992). Kanatlılarda Marek Hastalıg1 Ve Bursal Lezyonlar. Etlik Veteriner Mikrobiyoloji Dergisi, 7(3), 1-12.

Calnek, B.W., \& Witter, R.L. (1991). Marek's disease. Ninth Edition, Ames, Iowa, Iowa State University Press. 
Kahn, C.M. (2005). The Merck Veterinary Manual. Nineth Edition, Merck, Merial Publications.

National Research Council (1994). Nutrient Requirements of Poultry: Ninth Revised Edition, 1994. Washington, DC: The National Academies Press.https://doi.org/10.17226/2114.

Tayeb, I.T., Qader, G.K. (2012) Effect of Feed Supplementation of Selenium and Vitamin E on Production Performance and Some Hematological Parameters of Broiler. KSÜ Doğa Bil. Derg., 15(3), 46-56.

Yang, Z., Liu, C., Liu, C., Teng, X., Li, S. (2016). Selenium Deficiency Mainly Influences Antioxidant Selenoproteins Expression in Broiler Immune Organs. Biol Trace Elem Res., 172(1), 209-221. doi: 10.1007/s12011-015-0578-y. Epub 2015 Dec 3. PMID: 26631053.

Fischer, J., Bosse, A., Most, Erika., Müller, Andreas., Pallauf, J. (2008). Selenium requirement of growing male turkeys. British poultry science, 49. 583-91. 10.1080/00071660802 337258.

Scott, M. (1970). Feedstuffs, Yearbook, No. 42. 59-60

Konanç, K., Öztürk, E. (2012). Kanatlı Hayvan Beslemede Mineraller. 